\title{
DETECTION OF LEPTOSPIRA SPP. IN THE SEMEN AND URINE OF BULLS SEROLOGICALLY REACTIVE TO LEPTOSPIRA INTERROGANS SEROVAR HARDJO
}

\author{
Fernanda Senter Magajevski1 ${ }^{*}$; Raul Jose Silva Girio ${ }^{1}$; Luis Antonio Mathias ${ }^{1}$; Simone Myashiro²; \\ Margareth Élide Genovez² ; Eliana Pinheiro Scarcelli²
}

${ }^{1}$ Faculdade de Ciências Agrárias e Veterinárias, Departamento de Medicina Veterinária Preventiva, Universidade Estadual Paulista, Jaboticabal, SP, Brasil; ${ }^{2}$ Instituto Biológico de São Paulo, Departamento de Doenças Bacterianas da Reprodução, São Paulo, SP, Brasil

Submitted: September 23, 2003; Returned to authors for corrections: February 14, 2005; Approved: March 28, 2005

\begin{abstract}
This study evaluated PCR for the detection of leptospires in semen and urine of ten serologically reactive bulls, comparing these results with those obtained with other diagnosis techniques. Two collections of materials were done in alternate days. Semen and urine samples were separated in aliquots for: direct visualization in dark field microscopy; inoculation in hamsters (for semen only); isolation in culture media; and PCR. No hamster was positive by the microscopic agglutination test (MAT); kidney and liver fragments from the hamsters were used in an isolation attempt in culture media, with one positive isolation from the kidney of a hamster inoculated with semen of one bull, and from liver of hamsters inoculated with semen of three bulls. Isolation in culture was negative for all semen samples, but positive for five urine samples by direct inoculation. In PCR there was no positive result for semen samples, and only one urine sample was positive, which was coincident with one of the positive cultures. It was not possible to visualize leptospires in any of the samples by dark field microscopy.
\end{abstract}

Key words: Leptospira, semen, urine, PCR

\section{INTRODUCTION}

Among many diseases linked to reproduction, leptospirosis is one of the most important for the low productivity of cattle farming. Transmission of Leptospira spp. in cattle can happen in an indirect way through contact with contaminated water or soil, and directly through sexual contact. Once infected, the animal excretes the agent by the urine over a period of time which can be longer than one year and presents an intermittent character (14,21).

The presence of Leptospira spp. in semen of infected bulls was demonstrated naturally and experimentally, indicating the possibility of bovine leptospirosis transmission by natural coition or by artificial insemination $(15,20)$.

Around the world the criterion for leptospirosis diagnosis is a negative result by the microscopic agglutination test (MAT).
However, such condition is not an absolute assurance of absence of kidney infection. Hanson (8) reports an isolation of Leptospira spp. from urine or kidney tissue of serologically unreactive animals. Serology does not necessarily reflects the state of Leptospira carrier in bovines (23). Although MAT is a sensitive test, determining the serogroup involved, some disadvantages can be observed. The most important is the fact that it is an indirect test, which does not detect the presence of leptospires, but the immunological reaction of the infected host. Thus, the test does not indicate if the infection is active.

A definitive diagnosis of Leptospira spp. infection is usually given by cultivation and isolation of the agent; however, this procedure is expensive, demanding freshly collected samples, and at least 30 days are required to obtain conclusive results (1). Thiermann (21) reported that Leptospira spp. isolation, beyond the difficult execution, is dependent on factors like type

*Corresponding Author. Mailing address: Faculdade de Ciências Agrárias e Veterinárias, Departamento de Medicina Veterinária Preventiva, Universidade Estadual Paulista, 14884-900, Jaboticabal, SP, Brasil. Tel.: (+5516) 3209-2646, Fax: (+5516) 3202-4275. E-mail: f_magajevski@yahoo.com.br 
and uniformity of medium used, and the experience of the technician.

Due to the need of developing methods that offer greater sensitivity, specificity and speed, molecular biology techniques have been applied to detect leptospires.

Recently, the PCR technique became an important tool to detect infectious agents. It is a quick and extremely sensitive method that theoretically can detect a single DNA molecule in a few hours. Another great advantage of PCR is the fact that there is no need of viability of the pathogen for the use of the test, which allows inactivation and storage of samples, as well as application of the technique in poorly preserved samples (13).

PCR has been used successfully in several studies related to leptospirosis, either for detection of the agent in several materials, such as semen $(9,18)$, urine $(3,12,23)$ and aqueous humor (4), or to monitor leptospires density in blood and organs of experimentally infected hamsters treated with different doses of antibiotics (22).

The present study had as objective to evaluate the PCR technique for the diagnosis of bovine leptospirosis by detection of Leptospira in urine and semen of bulls serologically reactive to the serovar hardjo, comparing it with the results obtained by MAT and culture and isolation of the microorganism.

\section{MATERIALS AND METHODS}

\section{Examined animals}

The study was carried out with 10 semen donor bulls (Bos taurus) from an artificial insemination center located in the State of São Paulo. Animals serologically reactive to Leptospira interrogans serovar hardjo in two examinations one week apart, according to the routine of the insemination center, from March 2001 to July 2002, were selected; the lowest antibody titer for selection of an animal was 200. This titer was adopted to increase the possibility of finding leptospires in the materials studied.

\section{Sample collection}

Blood collection was performed by vein puncture, and the serum removed from the collected blood after clot retraction. Then the serum was identified and tested by the microscopic agglutination test (MAT).

Two semen samples from bulls reacting by the MAT were obtained, with a 3-day maximum interval, by the artificial vagina method.

Urine samples were collected from serologically reacting bulls by the technique of preputial massage immediately after semen collection.

\section{Microscopic agglutination test}

The sera were diluted in Sörensen buffered solution, with an initial dilution of $1 / 50$. From this dilution $50 \mu \mathrm{L}$ aliquots were placed in test tubes, and an equal amount of antigen added, resulting in a 1/100 dilution. The mixture serum-antigen was gently mixed and incubated in a bacteriological incubator at $28^{\circ} \mathrm{C}$ for two hours, and then read in a dark field microscope, with a $40 x$ objective and a $15 x$ eye piece. The criterion adopted to consider a serum reactive was $50 \%$ agglutination, that is, at least one half of the leptospires agglutinated in the microscope field at the amplification of 100 times (17). The reactive sera in the initial screening were reexamined with seven serial dilutions at the proportion of two, and only the animals with sera presenting a minimum titer of 200 were used. The serum titer was considered as the reciprocal of the greatest dilution that presented at least $50 \%$ agglutination.

\section{Detection of the agent}

The detection of leptospires in semen and urine was performed by: a) direct examination of semen suspensions, in an optical microscope with a 10x eye piece, and a 40x objective, and immersion dark field condenser (17); b) cultivation of leptospires in culture media with the serial dilution procedure (5); and c) extraction and detection of leptospire genetic material by the PCR technique. Isolation of leptospires was also performed by inoculation of $0.5 \mathrm{~mL}$ of semen, intraperitonealy, in male hamsters (Mesocricetos auratus) with 80 to $120 \mathrm{mg}$ live weight, and attempts of recovering the microorganisms from the kidneys and liver.

For the agent cultivation, semen and urine samples were processed as fast as possible (less than two hours time frame), and they were frozen at $-20^{\circ} \mathrm{C}$ until required for PCR examination.

\section{Detection of antibodies and attempt to isolate leptospires in hamsters}

Twenty one days after semen inoculation as described above, all hamsters, inoculated and controls (with application of sterile Sörensen solution), were individually anaesthetized in a chamber with ethyl ether vapors. Blood samples were collected by cardiac puncture, to detect antibodies against the serovar hardjo by the MAT; subsequently, a rigorous asepsis of the abdominal region was followed by a median laparotomy for removal of kidneys and liver of each hamster. Approximately $1 \mathrm{~g}$ of each aseptically collected organ was individually macerated in a sterile mortar and pestle, and suspended in $9 \mathrm{~mL}$ of sterile Sörensen solution.

\section{Isolation in culture media}

Starting from five serial dilutions at the proportion of 10 , with sterile Sörensen buffered solution, from a $0.5 \mathrm{~mL}$ aliquot of each studied sample (urine, semen, and hamster organ suspensions), cultivation of leptospires was done by seeding each dilution in Fletcher's (Difco) semisolid medium, amended with 5-fluorouracil (Hoffman - Roche), in the proportion of $200 \mu \mathrm{g} / \mathrm{mL}$ (5). After seeding, the tubes were incubated at $28^{\circ} \mathrm{C}$ for 12 weeks, observing the occurrence of an opalescence ring 
and weekly dark field microscopy studies were performed with a $40 x$ objective and a $15 x$ eye piece.

\section{Polymerase chain reaction (PCR)}

DNA extraction was done by enzymatic lysis with proteinase $\mathrm{K}$ followed by phenol-chloroform-isoamyl alcohol from $300 \mu \mathrm{L}$ of each sample (semen and urine); the DNA extraction steps were done basically as describe by Sambrook et al. (16).

The primer used was that proposed by Merien et al. (11), corresponding to nucleotides 38 to 57 (5'GGCGGCGC GTCTTAAACATG 3') and 348 to 369 (5'TTCCCCCATTGA GCAAGATT 3') of the 16 S rRNA gene primary structure of the Leptospira interrogans serovar canicola.

DNA sample amplification was done in $500 \mu \mathrm{L}$ microtubes, with a $50 \mu \mathrm{L}$ final volume. The reaction mixture consisted of $18.7 \mu \mathrm{L}$ ultrapure water, $5.0 \mu \mathrm{L} 10 \mathrm{x}$ reaction buffer $(500 \mathrm{mM} \mathrm{KCl}$; $15 \mathrm{mM} \mathrm{MgCl} ; 100 \mathrm{mM}$ tris-HCl, pH 9.0), 8.0 $\mu \mathrm{L}$ dNTPs mixture (200 mM of each nucleotide [dCTP, dATP, dGTP, dTTP]), $4.0 \mu \mathrm{L}$ each oligonucleotide $(10 \mathrm{pmol} / \mu \mathrm{L}), 0.3 \mu \mathrm{L}$ Taq DNA-polymerase ( 5 units per $\mu \mathrm{L}$ ) and $10 \mu \mathrm{L}$ extracted DNA sample, and the mixture was placed in a thermocycler.

The amplification cycle used was the one recommended by Merien et al. (11), added with an initial step at $94^{\circ} \mathrm{C}$ for 5 minutes.

Visualization of the amplified product (330 base pairs) was done by electrophoresis in a $2.0 \%(\mathrm{w} / \mathrm{v})$ agarose gel stained with ethidium bromide, using TBE $0.5 \mathrm{X}(0.04 \mathrm{M}$ tris-acetate and $0.001 \mathrm{M}$ EDTA, $\mathrm{pH} 8.0$ ) as running buffer (16).

\section{RESULTS}

By the direct dark field microscopy it was not possible to observe any leptospires in the 20 semen samples nor in the 18 urine ones, collected in duplicate from each one of the 10 serologically reactive bulls.

By the leptospires cultivation in culture media technique, no microorganisms were seen in the few semen cultures that did not get contaminated. It was possible to visualize leptospires in urine cultures of five bulls, in at least one of the collections (Table 1).

The results from Fletcher's semisolid medium culture of kidney and liver samples of hamsters inoculated with fresh "in natura" semen are presented in Table 1. They were grouped as a pool for each group of three hamsters that were inoculated with semen of the same bull and the same collection. It can be seen from Table 1 that Leptospira visualization was possible only from kidney cultures of hamsters that were inoculated with semen from bull 2 in both collections; however, it was possible cultivated leptospires in liver cultures of hamsters inoculated with semen from three bulls, in at least one collection. All tested hamsters were negative at the MAT. Negative results were obtained from cultures of liver and kidney of hamsters, as well as for MAT.

All positive cultures (urine of bulls, liver and kidney of hamsters) were confirmed by PCR.
Table 1. Results of attempts to detect Leptospira from urine of bulls and from kidney and liver of inoculated hamsters, by cultivation and PCR tests.

\begin{tabular}{|c|c|c|c|c|c|c|}
\hline Bull & $\begin{array}{c}\text { Sample } \\
\text { titers }\end{array}$ & $\begin{array}{l}\text { Serologic } \\
\text { (urine) }\end{array}$ & $\begin{array}{c}\text { Culture } \\
\text { (kidney*) }\end{array}$ & $\begin{array}{l}\text { Culture } \\
\text { (liver*) }\end{array}$ & $\begin{array}{l}\text { Culture } \\
\text { (urine) }\end{array}$ & PCR \\
\hline \multirow[t]{2}{*}{1} & 1 & 800 & $\mathrm{P}^{\mathrm{C}}$ & $\mathrm{N}$ & $\mathrm{P}^{\mathrm{C}}$ & $\mathrm{N}$ \\
\hline & 2 & 800 & $\mathrm{~N}$ & $\mathrm{~N}$ & $\mathrm{P}^{\mathrm{C}}$ & $\mathrm{N}$ \\
\hline \multirow{2}{*}{2} & 1 & 200 & $\mathrm{P}^{\mathrm{C}}$ & $\mathrm{P}^{\mathrm{C}}$ & $\mathrm{N}$ & $\mathrm{N}$ \\
\hline & 2 & 200 & $\mathrm{~N}$ & $\mathrm{P}^{\mathrm{C}}$ & $\mathrm{N}$ & $\mathrm{N}$ \\
\hline \multirow[t]{2}{*}{3} & 1 & 400 & $\mathrm{~N}$ & $\mathrm{~N}$ & $\mathrm{P}^{\mathrm{C}}$ & $\mathrm{N}$ \\
\hline & 2 & 400 & $\mathrm{~N}$ & $\mathrm{~N}$ & $\mathrm{~N}$ & $\mathrm{~N}$ \\
\hline \multirow[t]{2}{*}{4} & 1 & 400 & $\mathrm{~N}$ & $\mathrm{~N}$ & $\mathrm{~N}$ & $\mathrm{~N}$ \\
\hline & 2 & 400 & $\mathrm{P}^{\mathrm{C}}$ & $\mathrm{N}$ & $\mathrm{N}$ & $\mathrm{P}$ \\
\hline \multirow[t]{2}{*}{5} & 1 & 400 & $\mathrm{~N}$ & $\mathrm{~N}$ & $\mathrm{~N}$ & $\mathrm{~N}$ \\
\hline & 2 & 400 & C & $\mathrm{N}$ & $\mathrm{N}$ & $\mathrm{N}$ \\
\hline \multirow[t]{2}{*}{6} & 1 & 200 & $\mathrm{C}$ & $\mathrm{N}$ & $\mathrm{N}$ & $\mathrm{N}$ \\
\hline & 2 & 200 & $\mathrm{~N}$ & $\mathrm{~N}$ & $\mathrm{~N}$ & $\mathrm{~N}$ \\
\hline \multirow[t]{2}{*}{7} & 1 & 800 & $\mathrm{~N}$ & $\mathrm{~N}$ & $\mathrm{~N}$ & $\mathrm{~N}$ \\
\hline & 2 & 800 & $\mathrm{P}^{\mathrm{C}}$ & $\mathrm{N}$ & $\mathrm{N}$ & $\mathrm{N}$ \\
\hline \multirow[t]{2}{*}{8} & 1 & 200 & $\mathrm{~N}$ & $\mathrm{~N}$ & $\mathrm{~N}$ & $\mathrm{~N}$ \\
\hline & 2 & 200 & $\mathrm{~N}$ & $\mathrm{~N}$ & $\mathrm{~N}$ & $\mathrm{~N}$ \\
\hline \multirow[t]{2}{*}{9} & 1 & 400 & $X$ & $\mathrm{~N}$ & $\mathrm{P}^{\mathrm{C}}$ & $\mathrm{N}$ \\
\hline & 2 & 400 & $\mathrm{P}^{\mathrm{C}}$ & $\mathrm{N}$ & $\mathrm{N}$ & $\mathrm{N}$ \\
\hline \multirow[t]{2}{*}{10} & 1 & 200 & $X$ & $\mathrm{~N}$ & $\mathrm{~N}$ & $\mathrm{~N}$ \\
\hline & 2 & 200 & $\mathrm{~N}$ & $\mathrm{~N}$ & $\mathrm{~N}$ & $\mathrm{~N}$ \\
\hline
\end{tabular}

*"pool" three hamsters; "Confirmed by PCR; X: no coleted; $\mathrm{C}$ : contamineted; N: negative; P: positive.

It was not possible to detect bacterial DNA by PCR technique from the semen samples. Table 1 shows the PCR results from urine samples of Leptospira reactive bulls. It can be seen in the Table that the sample from second collection of bull 4 was the only one positive.

\section{DISCUSSION}

Undoubtedly, leptospirosis is one of the major diseases of the reproductive tract in cattle in Brazil and around the world, and the participation of semen as one of the dissemination vehicles was confirmed by several authors $(15,20)$, thus, requiring strict disease control in bulls which semen is used for artificial insemination, also caring for semen quality and the absence of leptospires in this material.

Leptospira spp. research in freshly collected semen and urine by direct dark field microscopy did not allow the visualization of leptospires in any of the two semen and urine samples of each animal. Direct visualization is very difficult, and a negative result does not mean absence of infection. 
Leptospira spp. isolation from semen samples was unsuccesessfull, with almost all cultivations being contaminated, even dilutions of $10^{-5}$. Similar frustrating results were obtained by Guimarães et al. (7) and Heinemann et al. (9). The failure of Leptospira isolation from the analyzed semen samples could be explained by the possible competition exerted by inhibitory and contaminant microorganisms present in this material (19). However, Brod et al. (2) evaluated semen of several sires and found that it was possible to observe leptospires during a direct examination after 24 hours of cultivation in a semisolid medium.

On the other hand, it was possible to detect leptospires in urine cultures from five bulls, in at least one of the collections. The fact that for the same bull it was possible to visualize Leptospira spp. in one collection, but not in another, could be explained by the intermittent character of leptospiruria (14), and also by the fact that possible contaminants inhibiting leptospires growth could be present in the urine. Thiermann (21) reported that a Leptospira spp. isolating in culture medium, besides being difficult to perform, is dependent on factors such as: type and uniformity of culture medium, and technician's experience.

In relation to the results of hamster inoculation with freshly collected semen, it was observed that the passage of material in laboratory animals could be a good alternative for isolation of Leptospira spp. from semen, which was also observed by Kiktenko et al. (10). Although the animals did not present any clinical alteration and the microscopic agglutination test at a $1 /$ 100 dilution of the sera turned negative, it was possible to visualize leptospires from kidney cultivation of a hamster group that received semen from one of the bulls, and from liver cultivation of hamster groups that received semen of three bulls.

The fact that the control group animals were MAT negative, and that it was not possible cultivate leptospires from kidney or liver, indicate that the hamsters did not present leptospirosis before inoculation.

Athough MAT is the most used technique for leptospirosis diagnosis, it presents some deficiencies, such as: false-negative results due to the low correlation between the carrier state and the presence of serum antibodies (23), difficulty of obtaining reproducible results between laboratories (21), and it is a time consuming technique, requiring the use of live leptospires as antigens (17).

Facing the deficiencies of MAT, the unspecificity, and the inadequacy of direct visualization of leptospires by dark field microscopy, and the difficulty of cultivating Leptospira spp. for isolation from several materials (21), PCR became a new diagnosis option, which is considered fast and extremely sensitive, theoretically being able to detect a single DNA molecule, since it passes through an amplification process.

This study has as major objective to evaluate PCR for the detection of leptospires in semen and urine of serologically reactive bulls. For this purpose, the initiator oligonucleotides Lep 1 and Lep 2, synthesized by Merien et al. (11) from the
Leptospira interrogans serovar canicola sequence of gene rRNA $16 \mathrm{~S}$ as determined by Fukunaga et al. (6), was selected, due to the fact that these primers were genus specific and allow the amplification of several serovars of non-pathogenic and pathogenic leptospires, including among them the serovars wolffi, hardjo, and pomona (9).

Although there are several successful reports of Leptospira spp. detection by PCR in semen $(9,18)$ and urine $(3,11,23)$, in the present study none of the semen samples were positive by PCR. For the urine samples, it was possible to detect Leptospira spp. DNA in only one, which was also positive for isolation. Theoretically, PCR can detect only one fragment of DNA, but some papers described different detection threshold, that is variable according to the sample, DNA extraction protocols and the primer used. Heinemann et al. (10) reported a detection threshold of 100 leptospires / $\mathrm{mL}$ in semen samples of bulls, with the same primers used in the present study.

New studies should be done in relation to the use of PCR for the diagnosis of leptospires in materials such as semen and urine, testing other DNA extraction methods, and other primers, since the results from this paper showed that sometimes isolation in culture medium or the passage through laboratory animals can yield better results.

\section{RESUMO}

\section{Detecção de Leptospira spp. em sêmen e urina de touros sorologicamente reagentes a Leptospira interrogans sorovar hardjo}

O presente trabalho avaliou a PCR na detecção de leptospiras em sêmen e urina de dez touros sorologicamente reagentes, comparando seus resultados com aqueles obtidos por outras técnicas de diagnóstico. Foram realizadas duas colheitas de materiais em dias alternados. As amostras de sêmen e de urina foram separadas em alíquotas para visualização direta em microscopia de campo escuro, inoculação em hamsters (apenas para o sêmen), isolamento em meio de cultura e PCR. Nenhum hamster apresentou positividade na prova de soroaglutinação microscópica (SAM); fragmentos de rins e fígado desses animais foram utilizados para a tentativa de isolamento em meio de cultura, sendo positivo o cultivo a partir do rim de hamster inoculado com semen de um touro, e do fígado de hamsters inoculados com o semen de três touros. O isolamento em meio de cultura foi negativo para todas as amostras de sêmen, mas foi positivo para cinco amostras de urina. Na PCR não houve resultado positivo para as amostras de sêmen, e apenas uma amostra de urina apresentou resultado positivo, sendo coincidente com uma das culturas positivas. Não foi possível visualizar leptospiras em nenhuma das amostras por exame direto em microscopia de campo escuro.

Palavras-chave: Leptospira, sêmen, urina, PCR 


\section{REFERENCES}

1. Bolin, C.A.; Zuerner, R.L.; Trueba, G. Comparison of three techniques to detect Leptospira interrogans serovar hardjo type hardjo-bovis in bovine urine. Am. J. Vet. Res., 50(7), 1001-1003, 1989.

2. Brod, C.S.; Martins, L.F.S.; Nussbaum, J.R.; Fehlberg, M.F.B.; Furtado, L.R.I.; Rosado, L.R.I. Leptospirose bovina na região sul do Estado do Rio Grande do Sul. Hora Vet., 14(84), 15-20, 1995

3. Cetinkaya, B.; Ertas, H.B.; Ongor, H.; Muz, A. Detection of leptospira species by polymerase chain reaction (PCR) in urine of cattle. Turk Vet. Hayv. Dergisi., 24(2), 123-130, 2000.

4. Faber, N.A.; Crawford, M.; Lefebvre, R.B.; Buyukmihci, N.C.; Madigan, J.E.; Willits, N.H. Detection of Leptospira spp. in the aqueous humor of horses with naturally acquired recurrent uveitis. $J$. Clin. Microbiol., 38(7), 2731-2733, 2000.

5. Faine, S. Guidelines for the control of leptospirosis. Genova: World Health Organization, 1982. $171 \mathrm{p}$.

6. Fukunaga, M.; Horie, I.; Okuzako, N.; Mifuchi, I. Nucleotide sequence of 16S rRNA gene for Leptospira interrogans serovar canicola strain Moulton. Nucleic Acids Res. Cexford., 18(2), 366, 1990.

7. Guimarães, M.S.C.; Santa Rosa, C.A.; Vasconcellos, S.A.; Oliveira, J.E.A.S.; Cortes, J.A. Diagnóstico da leptospirose em bovinos doadores de sêmen. Pesquisa de aglutininas séricas e tentativa de isolamento do agente a partir de amostras de sêmen. Rev. Bras. Rep. An., 31(1), 136-140, 1987.

8. Hanson, L.E. Immunology of bacterial diseases with special reference to leptospirosis. J. Am. Vet. Med. Assoc., 170, 991-994, 1977.

9. Heinemann, M.B.; Garcia, J.F.; Nunes, C.M.; Morais, Z.M.; Gregori, F.; Cortez, A.; Vasconcellos, S.A.; Visintin, J.A.; Richtzenhain, L.J. Detection of leptospires in bovine semen by polymerase chain reaction. Aust. Vet. J., 77(1), 32-34, 1999.

10. Heinemann, M.B.; Garcia, J.F.; Nunes, C.M.; Gregori, F.; Higa, Z.M.M.; Vasconcellos, S.A.; Richtzenhain, L.J. Detection and differentiation of Leptospira spp. serovars in bovine semen by polymerase chain reaction and restriction fragment length polymorphism. Vet. Microbiol., 73, 261-267, 2000.

11. Kiktenko, V.S.; Balashov, N.G.; Rodina, V.N. Leptospirosis infection through insemination of animals. J. Hyg. Epidemiol. Microbiol. Immunol., 20, 207-213, 1976.
12. Merien, F.; Amouriax, P.; Perolat, P.; Baranton, G.; Saint Girons, I. Polymerase chain reaction for detection of Leptospira spp. in clinical samples. J. Clin. Microbiol., 30(9), 2219-2224, 1992.

13. Merien, F.; Baraton, G.; Perolat, G. Comparison of polymerase chain reaction with microagglutination test and culture for diagnosis of leptospirosis. J. Infect. Dis., 172, 281-285, 1995.

14. Paul, P. S. Applications of nucleic acid probes in veterinary infectious diseases. Vet. Microbiol., 24, 409-417, 1990.

15. Rebhun, W.C. Diseases of Dairy Cattle. Baltimore: Willians \& Wilkins, 1995. p. 472-474.

16. Rodina, V.N.; Balashov, N.G., Leptospirosis infection of animals transmitted through insemination. XIX World Veterinary Congress, Mexico, 1971. 2, 707-708.

17. Sambrook, J.; Fritsch, E.F.; Maniatis, T. Molecular cloning: a laboratory manual. New York, Cold Spring Harbor Press, 957p. 1989.

18. Santa Rosa, C.A. Diagnóstico laboratorial das leptospiroses. Rev Microbiol., 1, 97-109, 1970

19. Scarcelli, E.; Genovez, M.E.; Piatti, R.M.; Girio, R.J.S.; Cardoso, M.C.V.; Miyashiro, S.; Castro, V. Detecção de Leptospira spp. em sêmen eqüino pela técnica da reação da polimerase em cadeia. XIV Reunião Anual do Instituto Biológico, São Paulo, 2001. p.102.

20. Schönberg, A. Studies on the effect of antibiotic substances on leptospires and their cultivation from material with a high bacterial count. Zent. Bakteriol. Parasit. Infektionsk. Hyg., 249, 400-406, 1981.

21. Sleigth, S.D.; Williams, J.A. Transmission of bovine leptospirosis by coition and artificial insemination. J. Am. Vet. Med. Assoc., 138 151-152, 1961

22. Thiermann, A.B. Leptospirosis: current developments and trends. $J$. Am. Vet. Med. Assoc., 184 (6), 722-725, 1984

23. Truccolo, J.; Charavay, F.; Merien, F.; Perolat, P. Quantitative PCR assay to evaluate ampicillin, ofloxacin, and doxycycline for treatment of experimental leptospirosis. Antimicrob. Agents Chemother, 46(3), 848-853, 2002.

24. Van Eys, G.J.J.M.; Gravekamp, C.; Gerritsen, M.J.; Quint, W.; Cornelissen, M.T.E.; Ter Schegget, J.; Terpstra, W.J. Detection of leptospiroses in urine by polymerase chain reaction. J. Clin. Microbiol., 27(10), 2258-2262, 1989. 